\title{
DIGITALISASI REGISTRASI DESA (LETTER C) TANAH DALAM OPTIMALISASI PELAYANAN DI TENGAH PANDEMI COVID19 DI PEMERINTAH DESA KECAMATAN SUSUKAN KABUPATEN CIREBON
}

\author{
Abdul Wahid, Rohadi \\ Universitas Muhammadiyah Cirebon \\ e-mail:abdul.wahid@umc.ac.id,rohadihadi24@yahoo.com
}

\begin{abstract}
Abstrak
Kondisi saat ini pemerintah desa di Kabupaten Cirebon dalam meyediakan informasi registrasi desa (letter $C$ ) masih menggunakan buku induk tanah yang rentan rusak karena kondisinya sudah lama dan belum diperbaharui. Proses pendaftaran tanah konversi hak tanah adat menjadi hak milik diperlukan suatu alat bukti salah satunya adalah registrasi desa (letter C). Untuk itu diperlukan, Pemerintah desa di Kecamatan Susukan Kabupaten Cirebon dapat berinovasi dengan memanfaatkan kemajuan teknologi dalam memberikan pelayanan registrasi desa (letter $C$ ) dengan konsep digitalisasi agar tercipta pemerintahan yang baik (good governance). Permasalahan penelitian ini tentang bagaimana peran Pemerintah Desa dalam memberikan pelayanan registrasi desa (letter C) di Kecamatan Susukan Kabupaten Cirebon dan bagaimana upaya Pemerintah Desa dalam memberikan pelayanan registrasi desa (letter C) dikaitkan dengan Instruksi Presiden Nomor 3 Tahun 2003 tentang Kebijakan dan Strategi Nasional Pengembangan e-government. Metode yang digunakan berupa penelitian yuridis empiris atau yuridis sosiologis. Spesifikasi penelitian ini adalah deskriptif analitis. Penelitian ini menggunakan data primer sebagai sumber data utama dan dibantu data sekunder sebagai sumber data pendukung. Data primer diperoleh dengan observasi dan wawancara. Pengumpulan data sekunder dilakukan dengan studi kepustakaan (library research).
\end{abstract}

Kata kunci: Digitalisasi, Letter C, Optimalisasi, Pelayanan, Pandemi Covid-19.

\begin{abstract}
The current condition of the village government in the Cirebon Regency in providing village registration information (letter $C$ ) is still using the land master book which is vulnerable to damage because its condition is old and has not been updated. The land registration process for converting customary land rights into property rights requires evidence, one of which is village registration (letter $C$ ). For this reason, it is necessary that the village government in Susukan District, Cirebon Regency can innovate by utilizing technological advances in providing village registration services (letter $C$ ) with the concept of digitalization to create good governance. The problem of this research is how the role of the Village Government in providing village registration services (letter C) in Susukan District, Cirebon Regency, and how the Village Government's efforts in providing village registration services (letter $C$ ) are associated with Presidential Instruction Number 3 of 2003 concerning National Development Policies and Strategies e-government. The method used is in the form of empirical juridical research or sociological juridical research. The specification of this research is descriptiveanalytical. This study uses primary data as the main data source and is assisted by secondary data as a source of supporting data. Primary data was obtained by observation and interviews. Secondary data collection is done by literature study (library research).
\end{abstract}

Keywords: Digitization, Letter C, Optimization, Services, Pandemic Covid-19. 


\section{A. Pendahuluan}

Adanya

Undang-Undang

Pokok Agraria yang ditindak lanjuti dengan adanya Peraturan Pemerintah Nomor 10 tahun 1961 yang kemudian diganti dengan Peraturan Pemerintah Nomor 24 Tahun 1997 tidak mungkin lagi diterbitkan hakhak yang tunduk kepada Kitab Undang-Undang Hukum Perdata ataupun yang akan tunduk kepada hukum adat setempat kecuali menerangkan bahwa hak-hak tersebut merupakan hak adat. Mengingat pentingnya pendaftaran hak milik adat atas tanah sebagai bukti kepemilikan hak atas tanah secara sah sesuai dengan Pasal 23, Pasal 32, dan Pasal 38 UndangUndang Pokok Agraria (UUPA), maka diberikan suatu kewajiban untuk mendaftarkan tanah adat khususnya hak milik Adat.

Akan tetapi kenyataannya belum optimal, mungkin mengenai kepastian hukum atas tanah tentang pendaftaran tanah. Dalam Pasal 19 UUPA mengharuskan pemerintah untuk mengadakan pendaftaran tanah di seluruh wilayah Republik Indonesia, dikarenakan masih minimnya pengetahuan, kesadaran masyarakat tentang bukti kepemilikan tanah. Mereka mengganggap tanah milik adat dengan kepemilikan berupa girik, yang Kutipan Letter C berada di Kelurahan/Desa merupakan bukti kepemilikan yang sah. Juga masih terjadinya peralihan hak seperti jual beli, hibah, kewarisan ataupun aktaakta yang belum didaftarkan sudah terjadi peralihan hak yang dasar perolehannya dari girik dan masih terjadinya mutasi girik yang didasarkan oleh akta-akta, tanpa didaftarkan di Kantor Pertanahan.

Tanah girik merupakan sebutan untuk tanah adat atau tanah yang belum memiliki sertifikat dan belum terdaftar pada Kantor
Pertanahan setempat, serta belum memiliki status hak tertentu (Hak Guna Bangunan, Hak Guna Usaha, Hak Pakai, Hak Milik). Tanah girik tidak memiliki status hukum yang kuat. Oleh karena itu, penting untuk mencermati tanah girik yang akan dibeli, agar di kemudian hari tidak timbul permasalahan yang merepotkan dan merugikan. ${ }^{1}$

Untuk menjamin kepastian hukum, ketertiban hukum dan memberikan perlindungan hukum bagi para pihak, maka perlu adanya kajian tentang jual beli tanah yang belum didaftarkan atau belum bersertifikat dengan kuasa menjual. Pemikiran secara teoritis kritis perlu dilakukan guna mengantisipasi dan mencegah terjadinya penyelundupan hukum dalam praktik peralihan hak atas tanah dengan cara jual beli, utamanya hak atas tanah yang belum didaftarkan atau belum bersertifikat, sehingga jual beli tanah yang belum bersertifikat ada kepastian hukum tanpa adanya penyalahgunaan hukum. $^{2}$

Guna untuk mendapatkan sertifikat atas tanah karena sangat berguna untuk menjamin kepastian hukum, ketertiban hukum dan memberikan perlindungan hukum atas tanah yang masyarakat miliki. ${ }^{3}$ Letter C merupakan tanda bukti pembayaran pajak tanah terhadap tanah milik adat. Diterbitkannya Letter C adalah untuk keperluan pemungutan pajak tanah dan pajak tersebut dikenakan pada pemilik atas nama tanah tersebut, sehingga muncul asumsi masyarakat yang

${ }^{1}$ Dinda Keumala dan Setiyono, Tanah dan Bangunan, Jakarta: Redaksi Raih ASA Sukses, 2009, 30 .

2 Andy Hartanto, Karakteristik Jual Beli Tanah yang Belum Terdaftar Ha katas Tanahnya, Surabaya: LaksBang Justisia, 2014, 83.

3 A. Hartanto, Karakteristik Jual Beli Tanah yang Belum Terdaftar Hakatas Tanahnya, Surabaya: Laksbang Justisia, 2014, 83. 
menganggap Letter $\mathrm{C}$ tersebut adalah sebagai bukti kepemilikan hak atas tanah. ${ }^{4}$ Posisi pendaftaran tanah merupakan bagian dari urusan agraria kemudian mengacu pada UUPA, ketentuan pendaftaran tanah pada UUPA terdapat dalam Pasal 19. Aturan ini kemudian diatur lebih lanjut melalui peraturan pelaksana, yaitu PP Nomor 10 tahun 1961 yang kemudian diganti dengan PP Nomor 24 Tahun 1997, hadirnya peraturan pelaksana ini menjadi jawaban akan kebutuhan kepastian hukum para pemilik tanah. ${ }^{5}$

Pelayanan publik merupakan tanggungjawab pemerintah dan dilaksanakan oleh instansi pemerintah, baik itu di pusat, di daerah, dan dilingkungan Badan Usaha Milik Negara. Pelayanan publik kepada masyarakat adalah salah satu tugas atau fungsi penting pemerintah dalam menyelenggarakan tugas-tugas pemerintahannya. Pelayanan publik merupakan unsur yang sangat penting dalam penyelenggaraan pemerintahan karena menyangkut aspek kehidupan yang sangat luas. Penyelenggaraan pelayanan publik merupakan upaya Negara untuk memenuhi kebutuhan dasar dan hakhak sipil setiap warga Negara atas barang, jasa, dan pelayanan administrasi yang disediakan oleh penyelenggara pelayanan publik.

Tuntutan terhadap peningkatan kualitas pelayanan publik terus berkembang seiring dengan semakin meningkatnya kesadaran bahwa warga Negara memiliki hak untuk dilayani, sedangkan kewajiban pemerintah adalah untuk memberikan pelayanan yang terbaik kepada masyarakat. Warga negara mempunyai hak untuk mendapatkan

${ }^{4}$ A. Sutedi, Peralihan Hak Atas Tanah dan Pendaftarannya, Jakarta: Sinar Grafika, 2007, 112. ${ }^{5}$ Ibid. pelayanan publik yang berkualitas dari negara (birokrasi). Warga negara juga memiliki hak untuk mendapatkan perlindungan akan hak-haknya, didengar suaranya, sekaligus dihargai nilai dan preferensinya. Dengan demikian, warga negara memiliki hak untuk menilai, menolak dan menuntut siapapun yang secara politis bertanggungjawab atas penyediaan pelayanan publik. Konsep ini disebut sebagai The New Public Service (NPS) yang dikembangkan oleh Janet V. Denhardt dan Robert B. Denhardt pada tahun 2003. Kinerja pelayanan publik dapat ditingkatkan apabila ada mekanisme exit dan voice. Mekanisme exit berarti bahwa jika pelayanan publik tidak berkualitas maka konsumen harus memiliki kesempatan untuk memilih lembaga penyelenggara pelayanan publik lain yang disukainya. Sedangkan mekanisme voice berarti adanya kesempatan untuk mengungkapkan ketidakpuasan kepada lembaga penyelenggara pelayanan publik. Pendekatan Pelayanan Publik Baru ini senada dengan Teori Exit dan Voice yang lebih dahulu dikembangkan oleh Albert Hirschman. ${ }^{6}$

Salah satu bentuk pelayanan publik yang diberikan pemerintah Desa di Kecamatan Susukan Kabupaten Cirebon adalah meyediakan informasi registrasi desa (letter C). Kondisi saat ini pemerintah desa di Kabupaten Cirebon dalam meyediakan informasi registrasi desa (letter C), hingga saat ini masih menggunakan buku induk tanah yang rentan rusak karena kondisinya sudah lama dan belum diperbaharui serta

6 Ratminto, Atik Septi Winarsih, Manajemen Pelayanan: Pengembangan Modal Konseptual, Penerapan Citizen's Charter dan Standar Pelayanan Minimal, Yogyakarta: Pustaka Pelajar, 2006, 71-72. 
membutuhkan waktu lama dalam mencari data ketika ada masyarakat yang membutuhkan informasi terkait registrasi desa (letter C). Tentunya membuat pemerintah desa di Kecamatan Susukan Kabupaten Cirebon harus bisa memenuhi kebutuhan pelayanan masyarakat dalam menyiapakan surat keterangan tanah (letter C) dari kepala desa atau lurah sebagai bukti awal guna pendaftaran tanah tersebut. Fenomena sekarang ini meningkatnya masyarakat desa ingin memperoleh kepastian hukum kepemilikan hak atas tanah, yaitu hal ini terbukti bahwa masyarakat desa mendaftarkan tanahnya.

Menurut Boedi Harsono bahwa pendaftaran tanah adalah suatu rangkaian kegiatan yang dilakukan oleh Negara/Pemerintah secara terus menerus dan teratur, berupa pengumpulan keterangan atau data tertentu mengenai tanah-tanah tertentu yang ada di wilayah-wilayah tertentu, pengolahan, penyimpanan, dan penyajiannya bagi kepentingan rakyat, dalam rangka memberikan jaminan kepastian hukum dibidang pertanahan, termasuk penerbitan tanda buktinya dan pemeliharaannya. $^{8}$

Merespon fenomena tersebut, Pemerintah desa di Kabupaten Cirebon harus dapat berinovasi dengan memanfaatkan kemajuan teknologi dalam memberikan pelayanan registrasi desa (letter C) dengan konsep digitalisasi agar tercipta pemerintahan yang baik (good governance). Konsep

${ }^{7}$ E. K. D. S. Abdul Wahid, "Kekuatan Alat Bukti Akta Otentik Terhadap Akta Pejabat Pembuat Akta Tanah (PPAT) Berdasarkan Peraturan Pemerintah Nomor 24 Tahun 2016 Juncto Pasal 1868 KUHPerdata," Mahkamah: Jurnal Kajian Hukum Islam, Vol. 4, No. 2, 2019.

8 B. Harsono, Hukum Agraria Indonesia, Sejarah Pembentukan Undang-Undang Pokok, Revisi ed., Jakarta: DJambatan, 2007, 72. digitalisasi registrasi desa (letter $\mathrm{C}$ ) sebagai pengalaman baru yang dahulu belum terbayangkan, digitaliasasi registrasi desa (letter C) banyak manfaat didapatkan dengan yaitu memberikan kemudahan, kecepatan, dan ketepatan mengakses registrasi desa (letter $\mathrm{C}$ ).

Permasalahan penelitian yuridis empiris atau yuridis sosiologis mengacu pada suatu fokus. Untuk fokus ini lebih spesifik pada informasi yang diperoleh dari lokasi penelitian. Penentuan fokus penelitian ini adalah digitalisasi registrasi desa (letter c) tanah dalam optimalisasi pelayanan di tengah pandemi covid-19 di Pemerintah Desa Kecamatan Susukan Kabupaten Cirebon. Berdasarkan uraian latar belakang tersebut yang menjadi permasalahan dalam penelitian ini adalah sebagai berikut:

1) Bagaimana peran Pemerintah Desa dalam pelayanan registrasi desa (letter C) di Kecamatan Susukan Kabupaten Cirebon?

2) Bagaimana upaya Pemerintah Desa memberikan pelayanan registrasi desa (letter C) dikaitkan Instruksi Presiden Nomor 3 Tahun 2003 tentang Kebijakan dan Strategi Nasional Pengembangan e-government?

\section{B. Metode Penelitian}

Metode pendekatan penulis dalam penelitian ini adalah pendekatan yuridis empiris atau yuridis sosiologis 9 . Atau dengan kata lain, kesesuaian antara law in books dengan law in action atau kesesuaian antara das sollen dengan das sein. ${ }^{10}$

${ }^{9}$ Penelitian hukum normatif bermula dari das solen (law in books) menuju das sein (law in actions), maka penelitian hukum sosiologis bermula dari das sein (law in actions) menuju ke das solen (law in books).

10 Zulfadli Barus, Analisis Filosofis tentang Peta Konseptual Penelitian Hukum Normatif dan Penelitian Hukum Empiris, Jurnal 
Penelitian ini bersifat deskriptif, yaitu suatu penelitian yang sematamata hanya menggambarkan (mendeskripsikan) keadaan dan kejadian atas suatu obyek yang diuraikan secara lengkap, rinci, jelas dan sistematis. Jenis penelitian ini adalah penelitian lapangan (field research) dengan metode pendekatan kualitatif sebagai proses penelitian menghasilkan data deskriptif berupa kata-kata tertulis atau lisan dari orang yang diamati.

\section{Peran Pemerintah Desa dalam Pelayanan Registrasi Desa (Letter C) Tanah}

\section{Tugas Pokok dan Fungsi Pemerintah Desa}

Menurut Thoha dalam Widodo secara teoritis sedikitnya ada tiga fungsi utama yang harus dijalankan oleh pemerintah tanpa memandang tingkatannya, yaitu fungsi pelayan masyarakat (public service function), fungsi pembangunan (development function) dan fungsi perlindungan (protection function). Pemerintah tidak harus berperan sebagai monopolist dalam pelaksanaan seluruh fungsi-fungsi tadi. Bagian dari fungsi tadi bias menjadi bidang tugas yang pelaksanaannya dapat dilimpahkan kepada pihak swasta ataupun dengan menggunakan pola kemitraan (partnership), antara pemerintah dengan swasta untuk mengadakannya. Pola kerjasama antara pemerintah dengan swasta dalam memberikan berbagai pelayanan kepada masyarakat tersebut sejalan dengan gagasan reinventing government yang dikembangkan Osborne dan Gaebler. ${ }^{11}$

Dinamika Hukum, Volume 13 No. 2, Mei 2013, 31.

${ }^{11}$ Osborne, David dan Gaebler, Mewirausahakan Birokrasi, Jakarta: PPM, 1995, 225.
Berdasarkan temuan penelitian dijelaskan bahwa secara umum Aparatur Pemerintah Desa merupakan alat penyelenggara pemerintahan desa maka aparatur pemerintah desa mempunyai tugas dan fungsi pokok dalam meningkatkan pelayanan kepada masyarakat. Tugas pokok aparatur pemerintah desa dalam pelayanan pelayanan registrasi desa (letter C) tanah pada masyarakat mencakup hal-hal berikut ini:

a) Kesederhanaan: Prosedur/tatacara pelayanan maksudnya aparatur pemerintah desa dalam memberikan pelayanan registrasi desa (letter C) tanah diselenggarakan secara mudah, lancar, cepat dan tidak berbelitbelit, mudah dipahami dan mudah dilaksanakan.

b) Kejelasan: Kejelasan dalam arti adanya kejelasan yang dipublikasikan/diumumkan dalam memberikan pelayanan aparatur pemerintah desa dengan memberikan informasi kepada masyarakat baik berupa persyaratan teknik atau persyaratan administratif.

c) Kelengkapan Sarana dan Prasarana: Kelengkapan sarana dan prasarana dalam arti tersedia sarana prasarana pelayanan yang memadai, mudah dijangkau oleh masyarakat dan dapat memanfaatkan teknologi telekomunikasi dan informatika (telematika).

d) Kedisiplinan kesopanan dan keramahan: Kedisiplinan, kesopanan dan keramahan dalam arti pemberi layanan harus bersikap disiplin, sopan dan santun, ramah, serta memberikan pelayanan dengan ikhlas.

e) Kenyamanan: Kenyamanan dalam arti lingkungan pelayanan harus tertib, teratur, disediakan ruang tunggu yang nyaman, bersih, rapi lingkungan yang indah dan sehat 
serta dilengkapi dengan fasilitas pendukung pelayanan, seperti parker, toilet, tempat ibadah dan lain-lain.

2. Pelaksanaan Pemerintahan Desa

Administrasi

Administrasi merupakan salah satu hal terpenting dalam penyelenggaraan pemerinthan di desa karena administrasi menjadi indikator penunjang dalam tata pelaksanaan pemerintahan, di pemerintahan Desa di Kabupaten Cirebon penataannya dilaksanakan melalui beberapa kegiatan antara lain kegiatan kependudukan, kegiatan pembangunan, kegiatan keuangan, dan kegiatan umum. Pelaksanaan Administrasi Pemerintah Desa pada hakekatnya sebagai bentuk kontribusi dalam meningkatkan peran setiap Pejabat Pemerintah Desa, guna penyelenggaraan Administrasi Desa pada dasarnya berlandaskan pada Undang-undang Nomor 6 Tahun 2014 tentang Desa. Serta mengacu pada Peraturan Meteri dalam Negeri Nomor 47 Tahun 2016 tentang Administrasi Pemerintahan Desa, dengan seksama mengatur penataan dan pembinaan administrasi Pemerintahan Desa yang tertera dalam Pasal 3 Peraturan Menteri Dalam Negeri No. 47 tahun 2016.

Pelayanan administrasi pada Pemerintah Desa Bunder, Kecamatan Susukan, Kabupaten Cirebon merupakan tata penyelenggaraan yang sangat penting karena dalam proses pemerintahan menyelenggarakan setiap pelayanan administrasi kepada masyarakat maupun dalam pembangunan dan juga pelaksanaannya disesuaikan dengan aturan dan standar pemerintahan yang berlaku untuk memenuhi segala kebutuhan masyarakat dalam melengkapi berkas yang mereka butuhkan sebagai warga negara. Guna meningkatkan sistem manajemen pemerintahan desa harus dilakukan penataan administrasi supaya bisa bekerja secara efisien dan efektif. Proses penataan administrasi desa sendiri adalah pencatatan informasi dan data untuk mendukung penyelenggaraan kegiatan pemerintahan desa. Karena itu, perlu dilakukan penyempurnaan pelaksanaan administrasi. Berikut beberapa jenis penyelenggaraan administrasi desa, diantaranya:

a) Administrasi Umum, yaitu aktivitas pencatatan informasi dan data tentang aktivitas pemerintahan desa dalam buku administrasi umum di kantor desa.

b) Administrasi penduduk ialah kegiatan pencatatan informasi dan data tentang kependudukan yang terdapat dalam buku administrasi penduduk yang ada di kantor desa.

c) Administrasi pembangunan yaitu kegiatan pencatatan informasi dan data pembangunan yang direncanakan, sedang berlangsung dan sudah dilaksanakan dalam buku administrasi pembangunan di kantor desa.

Jika dihubungkan dengan administrasi publik, pelayanan adalah kualitas pelayanan birokrat terhadap masyarakat. Kata kualitas memiliki banyak definisi yang berbeda dan bervariasi mulai dari yang konvensional hingga yang lebih strategis. Definisi konvensional dari kualitas biasanya menggambarkan karakteristik langsung dari suatu produk, seperti: ${ }^{12}$

a) Kinerja (performance)

b) Keandalan (reliability)

c) Mudah dalam penggunaan (easy of use)

d) Estetika (esthetics)

Adapun dalam definisi strategis

${ }^{12}$ Sinambela, Lijan Rochadi dkk, Reformasi Pelayanan Publik: Teori, Kebijakan, dan Implementasi, Jakarta: Bumi Aksara, 2006, 34. 
dinyatakan bahwa kualitas adalah segala sesuatu yang mampu memenuhi keinginan atau kebutuhan pelanggan (meeting the needs of customers). Gaspersz mengemukakan bahwa pada dasarnya kualitas mengacu kepada pengertian pokok: ${ }^{13}$

a) Kualitas terdiri atas sejumlah keistimewaan produk, baik keistimewaan langsung, maupun keistimewaan atraktif yang memenuhi keinginan pelanggan dan memberikan kepuasan atas penggunaan produk.

b) Kualitas terdiri atas segala sesuatu yang bebas dari kekurangan atau kerusakan.

c) Konsep kualitas bersifat relatif, maksudnya penilaian kualitas bergantung kepada perspektif yang digunakan untuk menentukan ciri-ciri pelayanan yang spesifik.

3. Pelayanan Registrasi Desa (Letter C) Tanah

Pelayanan registrasi desa (letter C) tanah di Desa Kecamatan Susukan sama dengan prosedur pelayanan yang ada di desa lain. Adapun prosedur dalam pelayanan registrasi desa (letter C) di Kantor Desa Bunder Kecamatan Susukan Kabupaten Cirebon, antara lain:

\section{a) Pelayanan Sederhana}

Pelayanan dalam pengurusan registrasi desa (letter C) tanah di tingkat Desa Bunder Kecamatan Susukan Kabupaten Cirebon dapat dikatakan berjalan baik. Hal ini di sampaikan oleh Sekretaris Desa Bunder bahwa: alur permohonan dimulai dari tingkat desa, si pemohon diminta untuk memenuhi persyaratan yang telah ditentukan, khusus untuk permohonan registrasi desa (letter C) tanah. Dengan adanya

13 Gasperz, Vincent, Manajemen Kualitas Dalam Industri Jasa, Jakarta: PT. Gramedia Pustaka, 1997, 37. alur permohonan dalam pengurusan registrasi desa (letter C) tanah sebagainya diharapkan masyarakat dengan mudah mengurus registrasi desa (letter C) tanah bagi yang memerlukan.

Kesederhanaan pelayanan ini membantu masyarakat dimana proses pelayanan dilakukan dengan mudah dipahami dan mudah dilaksanakan tanpa ada kesan berbelit-belit dari aparat pemerintah setempat.

b) Efisiensi Pelayanan

Untuk efisiennya pelayanan di kantor desa Bunder telah memberi arahan kepada bawahan untuk bekerja secara maksimal agar tidak terjadi keluhan di masyarakat, memang perlu diakui masih ada beberapa kekurangan dalam pelayanan namun kami terus berusaha memperbaikinya dengan meminta kritikan dan saran dari masyarakat untuk membangun pelayanan yang akan lebih baik. Persyaratan pelayanan hanya dibatasi pada hal-hal yang berkaitan langsung dengan pencapaian sasaran pelayanan dengan tetap memperhatikan keterpaduan antara persyaratan dengan produk pelayanan yang diberikan, guna mencegah adanya pengulangan pemenuhan persyaratan, dalam hal proses pelayanan masyarakat adanya kelengkapan persyaratan dari satuan kerja/instansi pemerintah lain yang terkait.

\section{c) Kepastian Pelayanan}

Pelaksana pelayanan dapat menjelaskan secara rinci prosedur serta persyaratan yang harus dilengkapi untuk mengurus registrasi desa (letter C) tanah yang berhubungan dengan kantor desa diminta atau tidak diminta aparat pelaksana harus melaksanakan tugasnya dengan sebaikbaiknya. Prosedur tersebut 
diatas telah di sosialisasikan dan diketahui oleh seluruh masyarakat.

Prosedur pelayanan yang ada di Desa Bunder Kecamatan Susukan Kabupaten Cirebon memang telah diketahui seluruh lapisan masyarakat yang ada terutama bagi pihak yang membutuhkan registrasi desa (letter C) tanah. Masyarakat setempat dalam hal pengurusan registrasi desa (letter C) tanah, terlebih dahulu harus ke Kantor Desa untuk mengambil formulir guna melengkapi berkas yang diperlukan ialah Surat Pengantar RT/RW, Foto copy dan asli KTP serta KK pemohon, Foto copy dan asli surat segel tanah atau surat perjanjian jual beli atau surat hibah atau surat pernyataan pembagian hak harta warisan atau surat wakaf dan lain-lain bermeterai $\quad 10.000 \quad$ yang tertera/tertulis dalam Daftar Buku C Desa/Letter C, Fotocopy SPPT PBB dan bukti lunas PBB/STTS PBB, Fotocopy KTP semua ahli waris dan/atau surat-surat lainnya yang tertera termasuk para saksi, Surat Pernyataan dan Surat Keterangan serta surat-surat lainlain yang diperlukan/dibutuhkan. Dengan adanya persyaratan yang sedemikian rupa pihak pelayananpun akan senang menjalankan tugasnya jika masyarakat tidak melakukan halhal yang bertentangan dengan prosedur yang berlaku.

\section{d) Keamanan Pelayanan}

Pelayanan yang diberikan sesuai dengan aturan formal yang diterapkan. Pemberian pelayanan yang telah menunjuk kepada aturan formal sangat diharapkan masyarakat sehingga aparat pelayanan bisa konsisten dalam menerapkan aturan hukum pelayanan tanpa ada kendala apapun. sejauh ini dalam segi keamanan dalam pelayanan di desa baik dan bisa bermanfaat.

e) Pelayanan yang Adil

Pelayanan yang diberikan kepada masyarakat mencakup seluruh lapisan masyarakat dan mengutamakan kepuasan dalam pelayanan. Pemerintah Desa Bunder dan Desa Jatipura tidak membeda-bedakan dalam memberikan pelayanan kepada masyarakat, memang perlu saya katakan bahwa perlu adanya prosedur yang jelas untuk melakukan pengurusan sesuatu yang berhubungan di desa.

\section{Strategi Pemerintah Desa dalam Pelayanan Registrasi Desa (Letter C) Tanah}

Pemerintah Desa memiliki peran signifikan dalam pengelolaan proses sosial di dalam masyarakat. Tugas utama yang harus diemban pemerintah desa adalah menciptakan kehidupan demokratis, memberikan pelayanan sosial yang baik sehingga dapat membawa warganya pada kehidupan yang sejahtera, rasa tenteram dan berkeadilan. Guna mewujudkan tugas tersebut, pemerintah desa dituntut untuk melakukan perubahan, baik dari segi kepemimpinan, kinerja birokrasi yang berorientasi pada pelayanan yang berkualitas dan bermakna, sehinggaperan pemerintah desa benar-benar makin mengarah pada praktek good local governance, bukannya bad governance. Dalam sebuah sistem pemerintahan desa untukmemajukan kesejahteraan umum, maka dibutuhkan suatu lemabaga birokrasi, dan dalam sistem sistem birokrasi ini tentunya juga membutuhkan aparat yang bekerja untuk mencapai sutu tujuannya tersendiri.

Dari hasil penelitian melalui wawancara bahwa peran Pemerintah Desa Bunder Kecamatan Susukan 
Kabupaten Cirebon sebagai pelaksanaan pemerintahan di desa dalam meningkatkan pelayanan publik kepada masyarakat sangatlah besar hal ini terlihat dari hasil wawancara dan observasi langsung terhadap kegiatan pelayanan di desa bahwa ditemukan adanya peran perangkat desa untuk meningkatkan pelayan publik kepada masyarakat yang terlihat dari sistem pelayanan yang dilakukan dan adanya perubahan-perubahan sistem layanan kepada masyarakat dengan strategi sebagai berikut:

Pertama, pendisiplinan aparatur desa yang berusaha memperbaiki dan membentuk pengetahuan, sikap dan perilaku aparatur desa sehingga aparatur tersebut secara sukarela berusaha bekerja secara kooperatif dengan rekan kerja dalam meningkatkan prestasi kerjanya. Disiplin adalah sikap dan tanggungjawab kejiwaan yang senantiasa mengikuti atau mematuhi keputusan yang ada dalam melaksankan sesuatu yang menjadi profesinya

Kedua, perubahan sistem pelayanan yang dilakukan oleh perangkat desa terkait pelayanan registrasi desa (letter $\mathrm{C}$ ) tanah yaitu menuju pelayanan registasi desa (letter C) tanah secara digital (digitalisasi registrasi (letter C) Tanah). Perubahan yang dilakukan dalam meningkatkan pelayanan publik kepada masyarakat perangakat desa memiliki tujuan yaitu untuk meningkatkan kepercayaan masyarakat terhadap pemerintahan desa maka dari itu memberikan pelayan yang baik merupakan suatu cara untuk menarik perhatian masyarakat. Guna meningkatkan sistem manajemen pemerintahan desa Bunder Kecamatan Susukan Kabupaten Cirebon melakukan penataan administrasi supaya bisa bekerja secara efisien dan efektif.
Ketiga, perbaikan berkelanjutan dari kinerja organisasi secara keseluruhan harus menjadi tujuan tetap dari organisasi. Prinsip perbaikan berkelanjutan diterapkan dengan cara berfokus pada upaya terus menerus meningkatkan efektifitas dan efisiensi organisasi untuk memenuhi kebijakan dan tujuan dari organisasi itu. Kepuasan masyarakat yang berurusan merupakan cerminan dari keberhasilan perangkat desa dalam menyediakan pelayanan perizinan terbaik.

Keempat, kerjasama aparatur desa dalam penyelenggaraan pemerintah desa merupakan salah satu indikator untuk melihat kinerja aparatur desa. Dalam hal ini kemampuan aparatur untuk bekerja sama dengan orang lain guna menyelesaikan tugas yang ditentukan sehinga hasil pekerjaannya akan semakin baik. Dengan demikian untuk menyelesaikan pekerjaannya masing-masing aparatur desa harus melakukan kerjasama dengan rekan kerjanya yang diharapkan mampu untuk membantu menyelesaikan pekerjaan yang dibebankan kepadanya, dimana aparatur tersebut berkolaborasi dengan rekan kerja dalam satu pekerjaan agar pekerjaan tersebut dapat selesai tepat pada waktunya.

\section{Upaya Pemerintah Desa dalam Pelayanan Registrasi Desa (Letter C) Tanah}

Berdasarkan hasil wawancara yang dilakukan dalam memberikan pelayanan registrasi desa (letter C) tanah Pemerintah Desa melakukan upaya atau langkah sebagai berikut:

\section{Penambahan Fasilitas}

Menambah fasilitas yang yang dimaksudkan oleh perangkat desa agara pelayanan yang diberikan kepada masyarakat tidak terjadi hambatan sehingga kinerja dari perangkat desa bisa berjalan dengan baik guna untuk mempermudah sistem 
pelayanan di kantor desa seperti menambah komputer atau alat print.

\section{Restorasi Registrasi Desa (Letter C) Tanah}

Buku $\mathrm{C}$ atau yang sering disebut sebagai letter $\mathrm{C}$ adalah Buku yang disimpan aparatur Desa, yang digunakan oleh Petugas Pemungut pajak untuk keperluan pembayaran pajak pada zaman Hindia Belanda. Biasanya isi Buku C yang lengkap terdiri dari:

a) Nomor Buku C;

b) Kohir;

c) Persil, Kelas Tanah, adalah suatu letak tanah dalam pembagiannya atau disebut juga (Blok);

d) Kelas Desa, maksud dari kelas desa adalah suatu kelas tanah yang dipergunakan untuk membedakan antara darat dan tanah sawah atau diantara tanah yang produktif dan non produktif ini terjadi pada saat menetukan pajak yang akan di pungut;

e) Daftar Pajak Bumi yang terdiri atas Nilai Pajak, Luasan Tanah dan Tahun Pajak;

f) Nama Pemilik Letter C, nama pemilik ini merupakan nama pemilik awal sampai pemilik terakhir;

g) Nomor urut pemilik;

h) Nomor bagian persil;

i) Tanda tangan dan stempel Kepala Desa/Kelurahan.

Sebelum berlakunya UndangUndang Pokok Agraria (UUPA) setiap terjadi peralihan hak tas tanah, baik peralihan secara jual beli, hibah atau waris, selalu dilakukan dihadapan Kepala Desa dan diikuti dengan perubahan data di Buku Letter C, dicatat nama pemilik baru dan sebabsebab perubahannya. Dengan demikian, Buku Letter $\mathrm{C}$ Desa menjadi dokumen penting yang perlu diselamatkan, mengingat semua catatan tentang riwayat setiap bidang tanah terangkum dalamnya. Dan mengingat usia Buku Letter $\mathrm{C}$ yang sudah tua, maka apabila tidak ada tindakan penyelematan buku tersebut akan mengalami kerusakan.

Atas dasar pemikiran tersebut, Pemerintah Desa Bunder, Desa Jatipura Kecamatan Susukan Kabupaten Cirebon memandang perlu untuk melakukan restorasi atas dokumen Buku Letter C desa. Karena Masyarakat Desa Bunder, Desa Jatipura Kecamatan Susukan Kabupaten Cirebon masih banyak yang menggunakan girik, petok $\mathrm{D}$, letter $\mathrm{C}$, rincik, kekitir, dan lain-lain serta hingga saat ini masih banyak yang menggunakan surat-surat tersebut sebagai alat bukti kepemilikan hak atas tanah. Pada masa penjajahan Belanda di Indonesia Petuk diterbitkan atas nama pemilik tanah yang merupakan dasar pengenaan dan penerimaan pajak disamping itu juga petuk dimaknai pengakuan hak atas tanah oleh si pembayar pajaknya sehingga muncul anggapan bahwa petuk merupakan tanda bukti kepemilikan hak atas tanah.

3. Digitalisasi Registrasi Desa (Letter C) Tanah

Pemerintah telah menetapkan program pembangunan pengembangan TIK dengan istilah E-goverment. Penerapan Egovernment merupakan amanat Inpres No.3 tahun 2003 tentang penyelanggaran tata kelola pemerintahan secara elektronis di Indonesia. Implementasi $e$ government dalam pelaksanaan tata kelola pemerintah dan pelayanan publik membutuhkan pemanfaatan teknologi informasi dan komunikasi beserta sumber daya manusia yang handal dalam mengelolanya.

Pemerintah Desa di Kabupaten Cirebon, mulai memproses untuk menerapkan digitalisasi buku letter C. Dalam rangka penerapan digitalisasi Registrasi Desa (Letter C) Tanah guna meningkatkan 
Pelayanan Publik khususnya dibidang pertanahan di desa, sebagai salah satu upaya dalam rangka digitalisasi tata kelola pemerintahan. Kecanggihan teknologi informasi saat ini sangat membantu pemerintah khususnya kepada Badan Pertanahan Nasional (BPN) Kabupaten Cirebon dalam memberikan pelayanan yang lebih maksimal dan lebih dekat kepada masyarakat. Oleh karenanya Pemerintah Desa di Kabupaten Cirebon juga telah menuju dan menggagas hal tersebut dengan memanfaatkan Sistem Informasi yaitu sebuah aplikasi yang dimanfaatkan untuk mengelola berbagai data pertanahan yang ada di desa untuk mendukung pelayanan desa. Salah satu produk dari adalah Sistem Informasi Manajemen Pelayanan Registrasi Desa (Letter C) Tanah merupakan aplikasi sistem pelayanan desa berbasis web yang terintegrasi dengan smartphone.

Dengan adanya aplikasi Registrasi Desa (Letter C) Tanah ini, maka menjadikan pemerintah desa lebih efektif dan efisien, menjadikan layanan publik lebih baik dan lebih akuntabel, menjadikan warga lebih aktif berpartisipasi dalam proses pembangunan desa, dan warga dapat memperoleh akses informasi tanah di desa lebih baik yang berfungsi untuk mendigitalisasi Registrasi Desa (Letter C) Tanah, sehingga prosesnya lebih mudah dan cepat, namun tetap harus sesuai dengan regulasi atau peraturan yang diterapkan pada masing-masing desa. Dengan adanya aplikasi ini dapat membantu masyarakat mengurus dokumen pertanahan di desa yang membutuhkan surat riwayat tanah dan lain-lain dari desa dengan lebih cepat dan juga memberikan kemudahan perangkat desa dalam mengerjakan administrasi terkait pertanahan di desa serta memudahkan dalam memberikan berbagai bentuk pelayanan kepada masyarakat.

Program ini adalah sebuah software aplikasi berbasis web (local host), yang digunakan untuk restorasi digital arsip pemerintah desa bidang pertanahan khususnya Buku Letter C, Aplikasi Arsip Pertanahan ini menggabungkan Buku C Desa, DHKP (SPPT) sehingga setiap jengkal tanah (Nama pemilik, Jenis Tanah, Letak Tanah, NOP, Ukuran Tanah, Sejarah Kepemilikan, dan lain-lain) terarsip dengan baik dan benar. penyelamatan arsip desa khususnya Buku Letter C, maupun meningkatkan pengamanan arsip melalui teknologi digital. Hal ini dikerjakan karena arsip Letter C Desa merupakan arsip vital terkait dengan data tanah di suatu desa, arsip letter $\mathrm{C}$ desa selalu dijadikan rujukan ketika ada permasalahan terkait dengan permasalahan tanah di desa sekaligus digunakan sebagai alat bukti hukum di pengadilan terkait sengketa tanah desa. Oleh karena itu arsip letter $\mathrm{C}$ desa harus di backup dan di amankan informasinya, digitalisasi arsip letter $\mathrm{C}$ desa adalah proses untuk membackup serta mengamankan informasi terkait dengan tanah di desadengan digitalisasi maka data data yang terkait dengan tanah milik masyarakat di desa menjadi aman.proses digitalisasi arsip letter $\mathrm{C}$ di desa dilakukan dengan beberapa tahapan diantara lain:

a) Sebelum dilakukan digitalisasi harus dilihat dahulu kondisi arsip letter c desa tersebut apakah kondisi tersebut masih baik atau sudah rapuh;

b) Persiapkan alat scan yang sesuai dengan kondisi arsip kalau arsip berbentuk lembaran dapat menggunakan alat scan yang berbentuk flatback (alat scan biasa), namun untuk arsip yang 
sudah rapuh dan berbentuk buku menggunakan scan khusus untuk scan buku;

c) Bersihkan kondisi arsip dan rapikan agar mudah dilakukan scanning;

d) Scan letter c desa dilakukan dengan 2 tahap yaitu arsip scan secara penuh dan arsip scan yang kemudian di cropping mengingat sering kali digunakan arsip letter $\mathrm{C}$ desa ditulis nama pemilik tanah;

e) Setelah dilakukan scan dan cropping maka dibuatkan daftar dalam bentuk microsoft excel yang akan digunakan sebagai database untuk masuk ke aplikasi microsoft access atau berbasis web;

f) Proses selanjutnya adalah mengupload gambar dalam aplikasi yang bersifat offline, aplikasi ini di dalam operasionalnya menggunakan fasilitas komputer/laptop.

Adapun tujuan dari program digitalisasi Registrasi Desa (Letter C) Tanah di Pemerintah Desa Kabupaten Cirebon adalah sebagai berikuit:

1) Pencatatan Riwayat Tanah

Sistem Pencatatan riwayat tanah terpadu sehingga administrasi pertanahan desa akan jauh lebih rapih dan tertib.

2) Penyelematan Letter $C$ Tanah Sebagai program penyelamatan arsip tanah desa khususnya buku letter $\mathrm{C}$ dari kerusakan, bencana alam, kehilangan dan penyalahgunaan. Sehingga desa mudah dalam Pencarian Data Tanah bisa dari Nama, No Persil, alamat Otentik (Buku C) tersimpan dalam bentuk Scan bisa dicetak.

3) Keamanan

Sebagai salah satu bentuk pengamanan arsip di era modern yaitu melalui digitalisasi arsip melalui teknologi sistem informasi yang ada.

\section{E. Penutup}

Berdasarkan uraian pembahasan tentang tersebut dapat disimpulkan bahwa:

1. Berdasarkan temuan penelitian dijelaskan bahwa secara umum Aparatur Pemerintah Desa melaksanakan peran terhadap pelayanan registrasi desa (letter C) tanah dengan melaksanakan pelayanan sederhana, efisiensi pelayanan, kepastian pelayanan, keamanan pelayanan, pelayanan yang adil.

2. Upaya yang dilakukan terhadap pelayanan registrasi desa (letter C) tanah Pemerintah Desa di Kecamatan Susukan Kabupaten Cirebon adalah Penambahan Fasilitas, Restorasi Registrasi Desa (Letter C) Tanah dan Digitalisasi Registrasi Desa (Letter C) Tanah.

\section{Daftar Pustaka}

A. Hartanto, Karakteristik Jual Beli Tanah yang Belum Terdaftar Ha katas Tanahnya, Surabaya: Laksbang Justisia, 2014.

A.Sutedi, Peralihan Hak Atas Tanah dan Pendaftarannya, Jakarta: Sinar Grafika, 2007.

Abdul Wahid, E. K. D. S, "Kekuatan Alat Bukti Akta Otentik Terhadap Akta Pejabat Pembuat Akta Tanah (PPAT) Berdasarkan Peraturan Pemerintah Nomor 24 Tahun 2016 Juncto Pasal 1868 KUHPerdata," Mahkamah: Jurnal Kajian Hukum Islam, Vol. 4, No. 2, 2019.

Andy Hartanto, Karakteristik Jual Beli Tanah yang Belum Terdaftar Ha katas Tanahnya, Surabaya: LaksBang Justisia, 2014. 
B. Harsono, Hukum Agraria Indonesia, Sejarah Pembentukan UndangUndang Pokok, Revisi ed., Jakarta: DJambatan, 2007.

Dinda Keumala dan Setiyono, Tanah dan Bangunan, Jakarta: Redaksi Raih ASA Sukses, 2009.

Gasperz, Vincent, Manajemen Kualitas Dalam Industri Jasa, Jakarta: PT. Gramedia Pustaka, 1997.

Osborne, David dan Gaebler, Mewirausahakan Birokrasi, Jakarta: PPM, 1995.

Ratminto, Atik Septi Winarsih, Manajemen Pelayanan: Pengembangan Modal Konseptual, Penerapan Citizen's Charter dan Standar Pelayanan Minimal, Yogyakarta: Pustaka Pelajar, 2006.

Sinambela, Lijan P. Rochadi dkk, Reformasi Pelayanan Publik: Teori, Kebijakan, dan Implementasi, Jakarta: Bumi Aksara, 2006.

Zulfadli Barus, Analisis Filosofis tentang Peta Konseptual Penelitian Hukum Normatif dan Penelitian Hukum Empiris, Jurnal Dinamika Hukum, Volume 13 No. 2, Mei 2013.

Undang-undang Nomor 6 Tahun 2014 Tentang Desa.

Peraturan Pemerintah Nomor 24 Tahun 1997 Tentang Pendaftaran Tanah.

Peraturan Pemerintah Nomor 10 tahun 1961 Tentang pendaftaran tanah.

Instruksi Presiden Nomor 3 Tahun 2003 Tentang Kebijakan dan Strategi Nasional Pengembangan $e$ government.

Peraturan Meteri dalam Negeri Nomor 47 Tahun 2016 tentang Administrasi Pemerintahan Desa.

\section{UCAPAN TERIMA KASIH}

Terima kasih penulis sampaikan kepada Direktorat Riset dan Pengabdian Masyarakat Deputi Bidang Penguatan Riset dan Pengembangan Kementrian Riset dan Teknologi/Badan Riset dan Inovasi Nasional yang telah memberikan dana hibah penelitian dosen pemula dengan Surat Perjanjian Penugasan Pelaksanaan Program Penelitian Nomor: 016/SP2H/RDPKR/LL4/2021; 026/1.b/LPPM/VII/2021.

Selanjutnya, terima kasih kepada ketua dan staff LPPM Universitas Muhammadiyah Cirebon yang telah memfasilitasi kegiatan PDP, dan seluruh pihak yang mendukung penelitian ini mulai dari penyusuan proposal hingga laporan penelitian 